\title{
Uji Sifat Fisik Cat Tembok yang Memanfaatkan pigmen warna Alami dari Daun Jati
}

\author{
Suhardi Effendy ${ }^{1 *}$, Agus Yulianto ${ }^{2}$ dan Ian Yulianti ${ }^{3}$ \\ *e-mail: ardifendy@gmail.com \\ ${ }^{1,2,3}$ Program Studi Magister Pendidikan Fisika, \\ Program Pascasarjana, \\ Universitas Negeri Semarang
}

\begin{abstract}
The purpose of this study was to determine the physical properties of wall paint by utilizing teak leaf extract containing carotenoids as natural dyes. Exploration of teak leaf extract is done by boiling teak leaves using $350 \mathrm{ml}$ of water until boiling and filtering with screen mash T100. As an adhesive used 75 grams of tapioca flour and quicklime mixture with a composition ratio of 1: $3,1: 1$ and $3: 1$. The solvents used are aqudes and fillers are white cement and PVAc glue. In this study the process of making paint is done by mixing all ingredients from pigments, adhesives, and solvents until homogeneous. Testing of the physical properties of paint, carried out through the test density, viscosity, and adhesion. The results of this study indicate that the composition of the most optimum paint formulation is found in the variation of adhesive with a ratio of $3: 1$ which results in a density value of $1.26 \mathrm{gr} / \mathrm{ml}$, viscosity 0.26 poise and adhesion power of $95 \%$.
\end{abstract}

Keywords: density test, viscosity, teak leaves and wall paint

\begin{abstract}
ABSTRAK
Tujuan dari penelitian ini mengetahui sifat fisik cat tembok dengan memanfaatkan ekstrak daun jati yang mengandung karotenoid sebagai pewarna alami. Eksplorasi ekstrak daun jati dilakukan dengan merebus daun jati menggunakan air $350 \mathrm{ml}$ sampai mendidih dan disaring dengan screen mash T100. Sebagai perekatnya digunakan campuran tepung tapioka dan kapur tohor sebanyak 75 gram dengan perbandingan komposisi 1:3, 1:1 dan 3:1. Pelarut yang digunakan aqudes dan bahan pengisi adalah semen putih dan lem PVAc. Pada penelitian ini proses pembuatan cat dilakukan dengan mencampurkan seluruh bahan dari pigmen, perekat, dan pelarut sampai homogen. Pengujian sifat fisik cat, dilakukan melalui uji densitas, viskositas, dan daya rekat. Hasil penelitian ini menunjukkan bahwa komposisi formulasi cat yang paling optimum terdapat pada variasi perekat dengan perbandingan 3:1 yang menghasilkan nilai densitas $1,26 \mathrm{gr} / \mathrm{ml}$, viskositas 0,26 poise dan daya rekat $95 \%$.
\end{abstract}

Kata Kunci:uji densitas, viskositas, daun jati dan cat tembok

\section{PENDAHULUAN}

Pigmen atau zat warna sering digunakan sebagai bahan tambahan pada produk pangan dan tekstil karena dapat memperbaiki tampilan warna (Yuliani, A dan Ferlina, F., 2005). Pewarna alami masih dapat dipakai dengan mengombinasikan zat warna sintetis misalnya, setelah diwarnai dengan zat warna alam hasilnya digabung dengan 
garam-garam pembangkit atau pengerjaan dengan logam(Siregar,2016).

Zat warna alami dapat diperoleh dari tanaman atau hewan. Warna alami ini meliputi pigmen yang terdapat dalam bahan atau terbentuk melalui proses pemanasan, penyimpanan atau perlakuan tertentu. Zat pewarna alami kini telah banyak digantikan oleh pewarna sintetis karena zat pewarna alami dipandang kurang stabil dan mudah mengalami perubahan baik fisik maupun kimiawi (Hidayati, R dan Marfu'ah, T. W., 2004).

Daun jati mengadung karotenoid yang berperan penting dalam pewarnaan (Hidayat, N., dan Saati, E. A. 2006). Pada industri pembuatan kain tenun ikat, pewarnaan batik dan makanan, pemanfaatan pewarna alami lebih disukai dibandingkan pewarna sintetis karena dapat memberikan ciri khas tersendiri [5].

Cat merupakan salah satu produk industri yang cukup penting saat ini yang digunakan untuk melapisi permukaan bahan sehingga permukaan tersebut menjadi lebih indah atau bernilai tinggi. Cat didefenisikan sebagai suatu cairan yang dipakai untuk melapisi permukaan suatu bahan dengan tujuan memperindah, memperkuat atau melindungi bahan tersebut. Pelekatan cat kepermukaan dapat dilakukan dengan berbagai cara diantaranya diusapkan, dilumurkan, dikuaskan atau disemprotkan (Ati, 2006). Komponen utama dalam sebuah cat adalah perekat (binder), pigmen, pelarut (solvent) dan bahan tambahan (additive) (Fachry, 2013).

Penggunaan pewarna alami dinilai lebih aman dibandingkan dengan pewarna sistesis, karna zat warna sintetis mengandung gugus azo yang sifat aromatiknya diduga keras menyebabkan penyakit kanker kulit (karsinogenik) dan kurang ramah lingkungan. Zat warna alam bersifat non karsinogenik dan memiliki keunggulan jika dibandingkan dengan zat warna sintetis, diantaranya adalah (a) intensitas warna terhadap kornea mata terasa sangat menyejukkan hingga dapat menyehatkan mata; (b) warna yang dihasilkan cenderung mengarah ke warna yang lembut dan warna yang berasal dari zat alam tidak dapat dicapai oleh zat warna sintetis; (c) zat warna alam mengandung antioksidan sehingga nyaman dan aman jika dipakai oleh manusia; dan (d) prosesnya ramah lingkungan(Siregar,2016).

Penelitian tentang pembuatan cat tembok yang menggunakan pewarna alam dengan bahan dasar tanaman kunyit telah dilakukan dengan proses ektrakasi menggunakan konsentrasi etanol $40 \%$, $60 \%$ dan $80 \%$. Cat yang dihasilkan memiliki ketahan warna yang baik terhdap suhu dan memenuhi standar mutu cat tembok (Fachry, 2013). Penelitian tentang pemanfaatan daun jati sebagai zat warna telah banyak dilakukan. Sebagai contoh (Diyah, B. S. D., Susinggih, W., dan Danang, P., 2015), melakukan penelitian tentang bagaimana Pengaruh Konsentrasi dan Jenis Bahan Fiksasi dalam Pemanfaatan Daun Jati (Tectona grandis Linn.f) sebagai Bahan Pewarna Alami Batik, dan (Rosyida, A dan Didik, A. W., 2014), melakukan penelitian tentang Pemanfaatan Daun Jati Muda untuk Pewarnaan Kain Kapas pada Suhu Kamar serta (Zulfa, L.,Sri K., dan Mas'ud E., 2014)yang melakukan penelitian tentang Ekstraksi Pewarna Alami dari Daun Jati (Tectona Grandis) (Kajian Konsentrasi Asam Sitrat dan Lama Ekstraksi) dan Analisa TeknoEkonomi Skala Laboratorium.

Berdasarkan uraian di atas, maka penelitian ini ditujukan untuk mengetahui sifat fisik cat tembok dengan memanfaatkan ekstrak daun jati yang mengandung karotenoid sebagai pewarna alami, sehingga menambah nilai jual pada daun jati dan mejadi bahan yang lebih berguna. 


\section{BAHAN DAN METODE}

Eksperimen pada penelitian ini dilakukan di Laboratorium Fisika Kemagnetan Jurusan Fisika Fakultas Matematika dan Ilmu Pengetahuan Alam Universitas Negeri Semarang.

Alat yang digunakan dalam penelitian ini adalah neraca digital, kassa penyaring screen mash T100, gelas ukur, viskometer ostwald, stopwatch, gunting, sendok, papan triplek, dan lakban atau selotip. Bahan yang digunakan dalam penelitian ini adalah Daun Jati, Tepung Tapioka, Kapur Tohor, Lem PVAC Putih, Semen Putih dan minyak Pinus.

\section{Proses Ekstraksi}

Proses ekstraksi diawali dengan mengidentifikasi karakter pewarna alami yang digunakan, sehingga dapat menentukan langkah dalam melakukan proses ekstraksi tersebut (Senthilkumar, dkk., 2015). Ekstraksi menggunakan pelarut didasarkan pada kelarutan komponen terhadap komponen lain dalam campuran. Hal yang sangat penting memahami penerapan pewarna alami dan mengidentifikasi kemungkinan metode ekstraksi yang digunakan, karena akan menghasilkan ekstraksi pewarna yang maksimal (Tassew A., dan Zenebesh T., 2014).

Proses ekstraksi untuk mengeksplorasi zat warna alam yang terdapat di dalam daun jati dilakukan dengan cara membersihkan dan memotong 200 gram daun jati dengan ukuran kecil, ditumbuk tetapi tidak sampai halus kemudian di masukkan dalam panci yang telah berisi pelarut air sebanyak $350 \mathrm{ml}$. Setelah itu rebus bahan hingga air berubah warna dan volume air menjadi $1 / 4$ dari volume awal. Menyaring dengan kassa screen mash T100 untuk memisahkan larutan dengan sisa bahan. Tunggu dingin larutan siap untuk digunakan.
Pembuatan cat dilakukan dengan terlebih dahulu membuat perekat (binder) dari campuran tepung tapioka dan kapur tohor dengan perbandingan 1:3 yaitu, tepung tapioka 18,75 gram dan kapur tohor 56,25 gram. Proses selanjutnya, sambil terus diaduk campurkan secara berurutan bahan-bahan yang lain lem PVAc putih 20 gram, semen putih 20 gram, larutan pigmen $90 \mathrm{ml}$ dan minyak pinus $10 \mathrm{ml}$. Ulangi langkah-langkah di atas untuk sampel yang lain dengan perbandingan perekat tepung tapioka dan kapur tohor 1:1 yaitu, tepung tapioka 37,5 gram dan kapur tohor 37,5 gram dan perbandingan perekat $3: 1$ yaitu, tepung tapioka 56,25 gram dan kapur tohor 18,75 gram.

Uji Densitas (Anonimous, 2009)

Pengujian densitas dilakukan dengan melakukan perhitungan antara masa/volume dari larutan yang akan diukur. Sampel yang telah dibuat diukur massa dan volumenya untuk mendapatkan nilai densitasnya.

\section{Uji Viskositas dengan viskometer Ostwald}

Metode ini ditentukan berdasarkan hukum Poisseulle menggunakan alat viskometer oswaltd. Penetapannya dilakukan dengan jalan mengukur waktu yang diperlukan untuk mengalirkan cairan dalam pipa kapiler dari a ke b. Cairan kemudian dihisap degan pompa kedalam pipa sampai diatas tanda a.Cairan dibiarkan mengalir kebawah dan waktu yang diperlukan dari a ke b dicatat menggunakan stopwatch. 


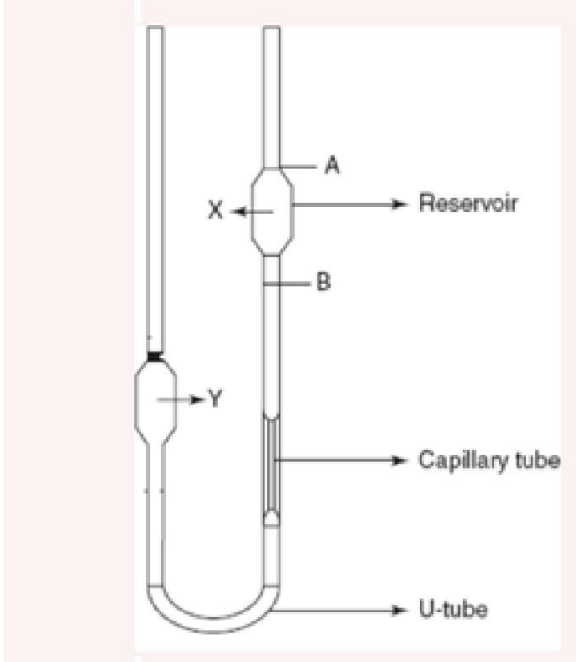

Gambar 1 viskometer Ostwald

Perhitunan nilai viskositas larutan dihitung dengan persamaan poisseulle.

Keterangan :

$$
\frac{\eta^{o}}{\eta}=\frac{\rho^{o} \cdot t_{o}}{\rho \cdot t}
$$

$\eta^{\mathrm{o}}=$ Vikositas cairan pembanding (poise).

$\eta=$ Viskositas cairan sampel (poise)

$\rho^{\mathrm{o}}=$ Densitas cairan pembanding (gram $/ \mathrm{ml})$.

$\rho=$ Densitas cairan sampel (gram $/ \mathrm{ml})$.

$\mathrm{t}_{\mathrm{o}}=$ Waktu aliran cairan pembanding (detik).

$\mathrm{t}=$ Waktu aliran cairan sampel (detik).

Uji Daya Rekat (ASTM, 1991)

Pengujian terhadap daya rekat suatu cat dilakukan dengan metode cross cut tape test. Uji daya rekat memakai lempeng uji sebuah triplek yang berukuran panjang $8,5 \mathrm{~cm}$ dan lebar 5,5 $\mathrm{cm}$. Langkah pengujian yaitu, 1) siapkan Triplek dengan panjang $8,5 \mathrm{~cm}$ dan lebar $5,5 \mathrm{~cm}, 2)$ lapisi permukaan triplek dengan cat yang telah dibuat, 3) bagi bagian triplek tersebut menjadi 100 bagian dengan menggunakan cutter dengan luas masing-masing $0,01 \mathrm{~cm} 2,3$ ) lekatkan bagian-bagian tersebut dengan pita perekat kemudian melepaskannnya kembali setelah kering. Ukur ketahanan rekat berdasarkan jumlah bagian cat yang masih menempel.

\section{HASIL DAN PEMBAHASAN}

Pengujian sifat fisik dapat dilakukan setelah pembuatan cat tembok dengan memanfaatkan pigmen warna pada daun jati telah dilakukan dengan cara dihomogenisasi. Rerata kadar karotenoid ekstrak pewarna alami daun jati muda berkisar antara 44,24380 $88,72259 \mathrm{mg} / 100 \mathrm{~g}$ [10].

\section{Pengaruh kualitas cat terhadap densitas}

Densitas suatu cat ditentukan oleh komponen-komponen penyusun yang ada di dalam cat. Penentuan densitas masingmasing sampel berpengaruh pada hiding power atau daya tutup cat pada saat diaplikasikan pada media. Komposisi yang tepat dari bahan pengikat, pewarna, dan pengering serta pengisi merupakan komponen yang dapat meningkatkan densitas suatu cat. Pelarut dan pengencer selain berfungsi mengatur kekentalan juga memiliki fungsi untuk menurunkan bobot jenis. Semakin kecil bobot jenis suatu larutan, maka akan makin baik pula larutan tersebut dapat diaplikasikan sebagai cat. Besarnya densitas yang dihasilkan pada penelitian dapat dilihat pada Gambar 3.

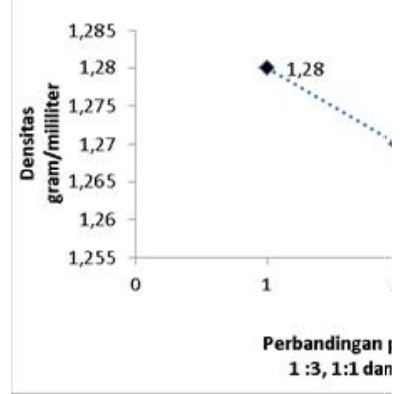

Gambar 2. Hubungan antara perbandingan bobot tepung tapioka dengan kapur tohor terhadap densitas cat. 
Berdasarkan Gambar 2 dapat dilihat bahwa nilai densitas paling tinggi terdapat pada sampel 1 dengan komposisi perekat tepung tapioka dan kapur tohor dengan perbandingan sebesar 1:3. Semakin tinggi konsentrasi larutan kapur tohor, maka semakin tinggi pula padatan yang terkandung dan menyebabkan naiknya densitas cat (Talbert,2008).

Padatan total cat akan berpengaruh terhadap densitas cat dan konsistensi dari film yang dihasilkan setelah diaplikasikan pada suatu permukaan. Semakin besar jumlah padatan total cat, maka semakin besar pula densitas cat secara keseluruhan. Bahan-bahan yang merupakan bahan padat adalah binder, lem PVAc dan bahan pengisi (filler). Densitas yang baik untuk kualitas cat adalah $1,2 \mathrm{gr} / \mathrm{ml}$ (Anonimous, 2009).

\section{Viskositas cat}

Cat dapat diaplikasikan dengan mudah jika memiliki kekentalan yang baik. Kekentalan merupakan salah satu parameter mutu cat yang dapat ditentukan secara visual. Besarnya viskositas yang dihasilkan dapat dilihat pada Gambar 3.

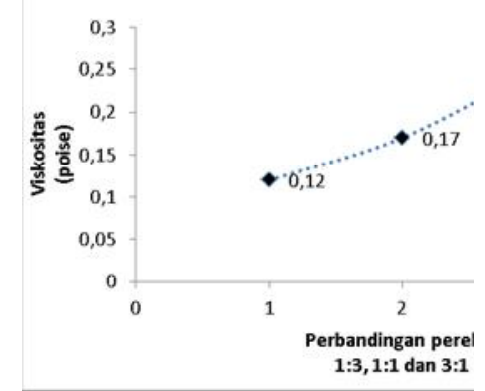

Gambar 3. Hubungan antara perbandingan bobot tepung tapioka dengan kapur tohor terhadap viskositas cat.

Pada gambar 3 dapat dianalisa bahwa semakin tinggi kadar tepung tapioka maka akan menghasilkan nilai viskositas yang semakin tinggi. Hal ini dapat terjadi karena sifat dari tepung tapioka yaitu mudah larut dalam air kemudian mengembang membentuk pasta sehingga meningkatkan nilai kekentalan. Hal ini berbanding terbalik dengan penggunaan kapur tohor, semakin meningkatnya penggunaan kapur tohor maka kekentalan cat akan semakin menurun. Nilai tertinggi yang di peroleh pada pengujian viskositas adalah 0,25 poise dan nilai terandahnya 0,12 poise.

\section{Daya rekat}

Daya rekat ialah kemampuan suatu cat tersebut dalam melekat pada suatu substrat/bidang yang dilapisi cat. Besarnya daya rekat yang dihasilkan pada penelitian dapat dilihat pada Gambar 4 .

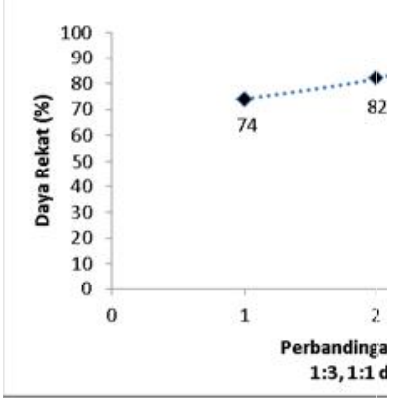

Gambar 4. Hubungan antara perbandingan bobot tepung tapioka dengan kapur tohor terhadap daya rekat cat.

Pada gambar 4 dapat diamati hubungan daya rekat cat terhadap komposisi tepung tapioka dengan kapur tohor, pembuatan cat tembok dengan daun jati sebagai pigmen warna ini menghasilkan daya rekat yang paling optimal pada komposisi perbandingan tepung tapioka dan kapur tohor sebesar 3:1 yaitu larutan dengan kandungan tepung tapioka paling banyak. Tepung tapioka mengadung senyawa amilopektin yang mempunyai sifat yang lengket. Sehingga, semakin banyaknya kandungan tepung tapioka maka akan semakin tinggi daya rekat cat tersebut. Hal tersebut berbanding terbalik dengan kapur tohor, 
semakin meningkatnya kapur tohor yang digunakan maka daya rekat cat juga akan semakin menurun. Nilai daya rekat optimal diperoleh $95 \%$ dan nilai daya rekat terendah diperoleh $74 \%$.

\section{KESIMPULAN}

Berdasarkan hasil penelitian dapat disimpulkan sifat fisik cat tembok berbahan dasar pigmen alami memiliki kualitas yang baik. Hasil pengujian nilai densitas, viskositas dan daya rekat cat yang paling optimal terdapat pada variasi perbandingan tepung tapioka dan kapur tohor sebesar 3:1 dengan nilai densitas $1,26 \mathrm{gr} / \mathrm{ml}$, viskositas 0,26 poise dan daya rekat $95 \%$. yang sesuai dengan SNI 3564-2009.

\section{DAFTAR PUSTAKA}

Yuliani, A dan Ferlina, F. (2005). Pembuatan Ekstrak Zat Warna Alami Tekstil dari Kunyit(Tesis, Universitas Negeri Surakarta).

Siregar, A.H. (2016). Pembuatan Zat Warna Alam Dari Tumbuhan Berasal Dari Daun. Jurnal Bina Teknika, 12(1), 103-110.

Hidayati, R dan Marfu'ah, T. W. (2004). Pembuatan Ekstrak Zat Warna Alami Tekstil dari Pinang(Tesis, Universitas Negeri Surakarta).

Hidayat, N., dan Saati, E. A. (2006). Membuat Pewarna Alami. Penerbit Trubus Agrisarana, Surabaya.

Ati, N. H. (2006). Komposisi dan Kandungan Pigmen Pewarna Alami Kain Tenun Ikat di Kabupaten Timor Tengah Selatan, Provinsi Nusa Tenggara Timor, Indo. J. Chem. 6(3), 325-331.

Rahman, A. (2014). Studi Pembuatan Cat Tembok Emulsi dengan Menggunakan Kapur sebagai Bahan Pengisi, Jurnal Rekayasa Kimia dan Industri10(2), 63-69.
Fachry, A.R. (2013). Ektraksi Senyawa Kurkuminoid dari Kunyit (Curcuma Longa Linn) sebagai Zat Pewarna Kuning pada Proses Pembuatan Cat (Skripsi, Universitas Sriwijaya,).

Diyah, B. S. D., Susinggih, W., dan Danang, P. (2015). Pengaruh Konsentrasi dan Jenis Bahan Fiksasi dalam Pemanfaatan Daun Jati (Tectona grandis Linn.f) sebagai Bahan Pewarna Alami Batik, Prosiding Seminar Agroindustri dan Lokakarya Nasional FKPT-TPI, 117-121.

Rosyida, A dan Didik, A. W., (2014). Pemanfaatan Daun Jati Muda untuk Pewarnaan Kain Kapas pada Suhu Kamar, Arena Tekstil, 29(2), 115-124.

Zulfa, L.,Sri K., dan Mas'ud E.(2014). Ekstraksi Pewarna Alami dari Daun Jati (Tectona Grandis) (Kajian Konsentrasi Asam Sitrat dan Lama Ekstraksi) dan Analisa Tekno-Ekonomi Skala Laboratorium, Jurnal Industria, 3(1) $62-72$.

Senthilkumar R. P., V. Bhuvaneshwari1, S. Sathiyavimal, R. Amsaveni, M. Kalaiselvi, dan Malayaman V.(2015). Natural Colours from Dyeing Plants for Textiles, International Journal of Biosciences and Nanosciences, 2(7), 160-174.

Tassew A., dan Zenebesh T. (2014). Application of Natural Dyes on Textile: A Review, International Journal of ResearchGranthaalayah, 1(2), 61-68.

Anonimous. (2009). Standar Nasional Indonesia SNI 3564:2009, Cat Tembok Emulsi, Dewan Standardisasi Nasional.

ASTM. (1991). Annual Book of ASTM Standars. Paints, Related Coatigs, and Aromatics, Volume 06.01. Paint- Test for formulated 
Products and Applied Coatings, American Society For Testing Materials. Philadelphia.

Talbert, R. (2008). Paint Technology Handbook. New York : CRC Press. 